Volume 14 (2) (2018): 135-150
Jurnal Borneo Administrator
p-issn : 1858-0300; e-issn : $2407-6767$
http://samarinda.lan.go.id/jba
$\mathrm{DOl}: 10.24258 / \mathrm{jba} . \mathrm{b} 14 \mathrm{i} 2.335$

\title{
SEBUAH PARADOKS : OPINI WTP DAN KESEJAHTERAAN RAKYAT
}

\section{UNQUALIFIED OPINION AND PUBLIC WELFARE : A PARADOX}

\author{
Musahadah $^{1}$ dan Rustan Amarullah² \\ Inspektorat Kabupaten Kotawaringin Barat ${ }^{1}$ \\ JI. H.M Rafi'i No. 16 Pangkalan Bun-Kalimantan Tengah \\ Pusat Kajian dan Pendidikan dan Pelatihan Aparatur III-Lembaga Administrasi \\ Negara $^{2}$ \\ JI. H.M Ardans No. 36 Samarinda-Kalimantan Timur \\ Email: musahadah-2015@feb.unai.ac.id ; rustanamarullah8@gmail.com
}

Naskah diterima: 29 Maret 2018; revisi terakhir: 30 Mei 2018; disetujui: 4 Juni 2018

\begin{abstract}
Unqualified Opinion (WTP) is the audit opinion that will be issued if the financial statements are considered to provide information that is free from material misstatement. This opinion became the dream of all local governments and even become a major performance indicator for the Inspectorate area. Nevertheless, the acquisition of the WTP opinion is still found to be contradictory to the welfare conditions of the people. This study qualitatively seeks to examine the need for an examination of financial governance that also includes indicators of people's welfare. The hermeneutic method is used to analyze the welfare audit discourse that needs to be carried out by BPK so that each rupiah of local government expenditure is beneficial for the improvement of people's welfare as well as in harmony with the WTP opinion obtained. The results of the research indicate that $B P K$ needs to include welfare audit in the process of local government financial audit from planning, implementation, to reporting activities that concretely support the achievement of public welfare. Thus, the philosophical management of statel regional finances is used openly, responsibly, and as much as possible for the welfare of the people can be realized. From the internal side of local government, it is necessary to strengthen the internal control system, as well as strict supervision from the Inspectorate.
\end{abstract}

Keywords: Society Welfare Audit, Hermeneutical, Unqualified Opinion, Government External Audit 


\begin{abstract}
Abstrak
Opini Wajar Tanpa Pengecualian (WTP) adalah opini audit yang akan diterbitkan jika laporan keuangan pemerintah dianggap memberikan informasi yang bebas dari salah saji material. Opini ini menjadi idaman seluruh Pemerintah Daerah bahkan menjadi indikator kinerja utama bagi Inspektorat daerahnya. Namun demikian, perolehan opini WTP tersebut masih ditemukan berkontradiksi dengan kondisi kesejahteraan rakyat. Penelitian ini secara kualitatif berupaya mendalami perlunya pemeriksaan tata kelola keuangan yang juga mengikutsertakan indikator kesejahteraan rakyat.Metode hermeneutik digunakan untuk menganalisis wacana audit kesejahteraan yang perlu dilaksanakan oleh BPK agar setiap rupiah belanja pemerintah daerah bermanfaat bagi peningkatan kesejahteraan rakyat serta selaras dengan opini WTP yang diperoleh. Hasil penelitian menunjukan pemaknaan bahwa BPK perlu memasukkan audit kesejahteraan dalam proses pemeriksaan keuangan pemerintah daerah mulai dari kegiatan perencanaan, pelaksanaan, hingga pada pelaporan yang secara konkrit mendukung pencapaian kesejahteraan masyarakat. Dengan demikian, filosofis pengelolaan keuangan negara/ daerah dipergunakan secara terbuka, bertanggung jawab, dan sebesar-besarnya untuk kemakmuran rakyat dapat diwujudkan. Dari sisi internal pemerintah daerah, diperlukan penguatan atas sistem pengendalian internal, serta pengawasan yang ketat dari Inspektorat.
\end{abstract}

Kata kunci: Audit Kesejahteraan Rakyat, Hermeneutika, WTP, Pemeriksaan Eksternal Pemerintah

\title{
A. PENDAHULUAN
}

Menilai sukses pembangunan dan kinerja pemerintah bukanlah sesuatu yang mudah. Peningkatan penilaian kinerja di sektor publik menyusul reformasi administrasi tahun 1980-an dan 1990-an memiliki konsekuensi terhadap kinerja itu sendiri. Tak jarang terdapat Performance Paradox yaitu adanya hubungan yang lemah antara indikator kinerja dengan kenyataan kinerja itu sendiri (Thiel dan Leeuw, 2002). Untuk menilai keberhasilan dalam pemerintah daerah, tak jarang opini BPK dijadikan sebuah acuan utama dan menjadi Indikator Kinerja dalam Rencana Strategi Organisasi Pengawasan (Inspektorat). Namun indikator ini menjadi kehilangan nilai karena hubungan antara yang dilaporkan (Laporan Keuangan Pemerintah Daerah) dengan kondisi faktual di lapangan berbeda.

Konsep transparan dan akuntabel dalam tata kelola keuangan pada manajemen pemerintahan merupakan suatu kewajiban yang harus dijalankan oleh birokrasi yang diberi amanah mengelola keuangan negara. Dalam hal ini, akuntabilitas dimaksudkan apakah dana yang diamanatkan digunakan dengan cara yang benar sesuai dengan undang-undang atau peraturan yang telah ditentukan. Dengan demikian audit adalah salah satu cara langkah yang harus ditempuh untuk mengetahui tingkat akuntabilitas pemerintah, yaitu sejauh mana ketepatan dan kepatuhan pemerintah terhadap peraturan perundang-undangan dalam menjalankan anggaran. Pemberian opini Wajar Tanpa Pengecualian (WTP) oleh BPK merupakan proses awal dari tercapainya akuntabilitas secara penuh. Begitu juga menurut pandangan dari paradigma New Public Manajement (NPM), apa yang dilakukan pemerintah harus berorientasi pada hasil, setiap anggaran pada satuan unit kerja ditujukan pada kemakmuran rakyat.

Untuk memperoleh pencapaian opini WTP bukanlah hal yang mudah. Proses menyusun laporan keuangan yang sesuai Standar Akuntansi Pemerintahan (SAP) perlu perjuangan ekstra. Kelemahan 
pada sistem pengendalian internal internal, keterbatasan SDM yang paham akuntansi pemerintahan dan ditambah ruwet dengan berbagai kepentingan politik yang menunggangi sehingga terjadi penggunaan anggaran yang cenderung menabrak aturan menyebabkan penyajian laporan keuangan yang akuntabel benar-benar bukanlah hal yang mudah. Pemberian apresiasi atas pencapaian opini WTP kepada lembaga pemerintah menjadi hal yang wajar dengan adanya berbagai kesulitan tersebut. Namun demikian, seharusnya obsesi memperoleh opini WTP bukan sekedar tujuan jangka pendek semata, namun lebih sebagai bentuk akuntabilitas dan tanggung jawab pengelolaan keuangan negara secara benar (Putry dan Badrudin, 2017:24).

Berdasarkan Undang-undang Nomor 15 Tahun 2004 tentang Pemeriksaan Pengelolaan dan Tanggung Jawab Keuangan Negara dalam Pasal 3 menjelaskan bahwa BPK mempunyai tugas untuk mengaudit pertanggung jawaban keuangan negara baik pertanggungjawaban pemerintah pusat maupun pemerintah daerah. Namun dalam pelaksanaan penyampaian laporan pertanggungjawaban tersebut, masih banyak elemen masyarakat meragukan hubungan antara opini audit laporan keuangan (LK) dengan kesejahteraan rakyat. Keraguan tersebut bisa diterima, mengingat fakta ada daerah yang mendapat opini WTP namun indikator-indikator kemiskinan, pengangguran, dan Gini Ratio (kesenjangan pendapatan)-nya masih belum menunjukkan tercapainya kesejahteraan.

Demikian pula sebaliknya, ada daerah yang menunjukkan pencapaian kesejahteraan masyarakat yang baik, namun memperoleh opini non WTP. Sebagaimana penelitian Akbar dan Djazuli (2015) tentang Audit Keuangan dan Kesejahteraan Rakyat di Kabupaten Badung, Tabanan, dan Kota Denpasar Tahun 2013 yang menyebutkan diantaranya bahwa Kabupaten Badung yang berhasil mencapai indikator-indikator kesejahteraan ekonomi yang lebih baik dibandingkan Kabupaten/ Kota lainnya di Bali namun memperoleh opini TW yang tidak lebih baik dibandingkan dengan Kabupaten/Kota lainnya. Sedangkan Kabupaten Tabanan yang indikator kesejahteraan ekonominya kurang bagus mendapatkan opini WDP. Untuk Kota Denpasar dengan indikator kesejahteraan yang tinggi sejalan dengan opini WTP yang diperolehnya. Demikian halnya dengan Kabupaten Bangli yang mendapatkan opini TMP yang juga sejalan dengan indikator kesejahteraan ekonomi yang tidak terlalu tinggi. Di sisi lain Kabupaten Jembrana dan Karangasem yang kesejahteraan ekonominya tidak begitu baik namun mendapatkan opini WDP.

Penelitian terkait juga dilakukan oleh Putry dan Badrudin (2017:33), dengan menguji pengaruh kinerja keuangan pemerintah daerah pada opini audit dan kesejahteraan masyarakat di DIYogyakarta. Dengan menggunakan Struktural Equation Model-Partial Least Square (PLS-SEM) penelitian ini menemukan bahwa kinerja keuangan berpengaruh positif dan signifikan pada opini audit pemerintah dan kesejahteraan masyarakat DIY. Hasil penelitian ini sejalan dengan dengan penelitian Ni Nyoman, et al. (2015) yang menunjukkan bahwa kinerja keuangan pemerintah daerah berpengaruh positif terhadap kesejahteraan masyarakat. Jadi, semakin meningkatnya kinerja keuangan pemerintah daerah (diproksikan dengan penerimaan PAD dibagi dengan jumlah pendapatan transfer dari pemerintah pusat, kemampuan daerah dalam meningkatkan keberhasilan yang telah dicapai, dan prioritas alokasi dana pada belanja pembangunan) maka semakin mampu mengelola potensi daerahnya yaitu SDA, SDM, dan sumber daya keuangannya secara optimal sehingga berpengaruh pada semakin meningkatnya kesejahteraan masyarakat.

Perbedaan hasil penelitian sebelumnya tersebut mengindikasikan bahwa masih terdapat keraguan hubungan yang positif dan linear antara pencapaian opini WTP (pengelolaan keuangan) dan meningkatnya kesejahteraan masyarakat. Idealnya, semakin baik pengelolaan keuangan negara yang dilakukan pemerintah yang salah satu indikatornya adalah mendapatkan opini WTP dari BPK, maka semakin meningkat pula kesejahteraan masyarakatnya. Karena sejatinya, penggunaan keuangan negara, diperuntukkan untuk sebesar-besarnya bagi kesejahteraan rakyat. Konsep kesejahteraan 
sangat relevan untuk membahas hubungan antara kinerja pemerintahaan dalam pengelolaan keuangan negara dengan opini BPK, sebab indikator kesejahteraan merupakan output dan outcome yang dihasilkan atas sumber daya ekonomi melalui aktivitas-aktivitas atau program-program pemerintah. Dalam konsep value for money, input yang digunakan harus bisa menghasilkan output yang diinginkan dan juga harus meberikan outcome yang baik bagi masyarakat.

Terkait dengan konsep kesejahteraan tersebut, BPK sebagai lembaga negara yang bertugas memeriksa pengelolaan dan tanggung jawab keuangan negara, wajib menilai dan memastikan apakah kebijakan yang diambil dan dipilih oleh pemerintah adalah kebijakan publik yang sudah baik dan tepat. Konstitusi mengamanatkan pengelolaan keuangan negara untuk kesejahteraan rakyat sehingga harus diselenggarakan secara tertib, taat, efektif, efisien, transparan, dan bertanggung jawab. Dalam konteks ini, fokus utama penggunaan anggaran negara adalah kualitas kinerja pemerintah dalam merealisasikan program-program pembangunan yang dibiayai oleh negara. Apakah program-program pemerintah itu berdampak pada upaya menekan angka pengangguran, mengurangi kemiskinan, Gini Ratio (kesenjangan pendapatan), dan meningkatkan Indeks Pembangunan Manusia (IPM).

BPK mengakui bahwa pemeriksaan keuangan yang selama ini dilakukan masih sebatas berkaitan dengan sistem administrasi keuangan apakah transaksi keuangan sudah dicatat dan dilaporkan sesuai dengan standar akuntansi pemerintah. Untuk menjawab kondisi tersebut di atas, BPK merencanakan untuk memperbanyak dan meningkatkan kualitas audit kinerja (Azis, 2017). Dalam renstra BPK 2016-2020 mensyaratkan pemeriksaan-pemeriksaan yang akan dilakukan adalah bertujuan mendorong terwujudnya pembangunan untuk sebesar-besarnya kemakmuran rakyat sebagai refleksi dari peningkatan kematangan BPK. Audit yang dilakukan BPK diharapkan mampu menilai dan mengevaluasi program-program pembangunan pemerintah didesain untuk mencapai dampak yang diinginkan yakni meningkatkan kesejahteraan rakyat.

Berdasarkan tingkat pemerintahan, opini WTP dicapai oleh 31 dari 34 pemerintah provinsi (91\%), 275 dari 415 pemerintah kabupaten (66\%), dan 72 dari 93 pemerintah kota (77\%). Capaian opini tersebut telah melampaui target kinerja keuangan daerah bidang penguatan tata kelola pemda/ program peningkatan kapasitas keuangan pemda yang ditetapkan dalam RPJMN 2015-2019 masing-masing sebesar $85 \%, 60 \%$, dan $65 \%$ pada tahun 2019 . Meskipun demikian, pemeriksaan yang dilakukan atas 205 objek pemeriksaan pada pemerintah daerah tersebut menunjukkan hasil pemeriksaan kinerja pada pemerintah daerah yang secara umum menyimpulkan bahwa pelaksanaan kegiatan atas objek pemeriksaan belum sepenuhnya efektif(BPK, 2018:xliii). Kesimpulan ini tentu mengisyaratkan bahwa pengelolaan keuangan negara, relatif masih jauh dari esensi, yaitu menyejahterakan rakyat.

Berdasarkan uraian di atas, penelitiàn ini berupaya mengupas secara komprehensif perlunya pelaksanaan audit kesejahteraan rakyat agar terinsepsi kedalam regulasi dan dapat terlaksana dengan baik pada proses audit keuangan pemerintah. Adapun kontribusi penelitian ini meliputi hal-hal sebagai berikut: (1) secara teori, penelitiàn ini diharàpkan dàpat digunàkan sebàgai bahàn referensi sertà màsukan lebih lànjut tentang pengawasan dan bermànfaat bàgi pengembangan teori dalàm bidàng ilmu akuntànsi khususnyà audit sektor pemerintàh; (2) penelitiàn ini dapàt digunàkan sebàgai bahàn pertimbangan dàn informàsi bàgi pemerintah untuk mengkaji audit keuangan pada Pemerintah Daerah dengàn mempertimbangkan indikator kesejahteraan rakyat agàr opini yang diperoleh benar-benar menggambarkan kondisi faktual capaian kinerja pemerintah daerah dan mencapai tujuan nasional seutuhnya. 


\section{B. METODE PENELITIAN}

Penelitian ini merupakan penelitian kualitatifdengan pendekatan interpretifatau lebih khususnya dengan model pendekatan hermeneutika. Pendekatan ini digunakan untuk menafsirkan makna kata audit kesejahteraan rakyat secara lebih mendalam dalam rangka berupaya menjelaskan dan menelusuri pesan dan pengertian dari sebuah ucapan atau tulisan yang tidak jelas, kabur, remang-remang, dan kontradiktif, yang menimbulkan kebingungan bagi pendengar atau pembaca (Faiz, 2003:22). Selain itu juga pendekatan hermeneutika digunakan sebagai proses mengubah sesuatu atau situasi ketidaktahuan menjadi mengerti terutama proses ini melibatkan bahasa sebab bahasa merupakan mediasi paling sempurna dalam proses (Palmer, 2003:15). Definisi sederhana hermeneutik adalah interpretasi teks atau menemukan makna dari suatu tulisan (Wahyuni 2015:170).

Pendekatan hermeneutik bahkan dapat memberikan gambaran bagi peneliti untuk memahami bagaimana subjek menginterpretasikan suatu hal dan berperilaku sesuai dengan interpretasi mereka. Hal ini berarti hermeneutik sebagai mode analisis jelas dapat digunakan untuk sebuah analisis. Analisis ini diharapkan mampu menjangkau penjelasan yang mungkin terbatas dalam matematika atau statistika, untuk dapat memberikan kita hasil yang lebih reflektifAditantra (2011:20)

Penelitian ini berupaya untuk mengungkapkan makna berdasarkan apa yang ada dalam suatu ungkapan atau teks, dengan cara menggali keterangan dari nara sumber aslinya, dan berupaya menyampaikan makna agar dapat dipahami sesuai dengan keadaan dan konteks yang sebenarnya. Audit kesejahteraan rakyat adalah sebuah wacana atau teks yang dilontarkan oleh Harry Azhar Azis saat terpilih sebagai ketua BPK periode tahun 2014-2019 dan menjadi fokus kebijakan BPK yang tercantum dalam renstra tahun 2016-2020, sehingga diharapkan penelitian ini akan memberikan informasi dan sudut pandang yang lebih luas dari sebuah ungkapan makna "audit kesejahteraan rakyat".

\section{Sumber Data}

Sumber data dalam penelitian ini berasal dari hasil wawancara dengan informan. Informan merupakan orang yang menyampaikan dan mengungkapkan istilah audit kesejahteraan rakyat dan bersedia untuk memberikan keterangan atas istilah tersebut. Informan dalam penelitian ini adalah Ketua BPK RI periode Tahun 2014-2019 dan masih menjabat sampai saat penelitian dilakukan, sehingga informan adalah orang yang representatif karena merupakan sumber pertama (primer) penyampai teks atau makna aslinya.

\section{Teknik Pengumpulan Data}

Teknik pengumpulan data dalam penelitian ini dengan cara yang pertama adalah mewancancarai informan secara mendalam untuk mengetahui tentang apa yang ingin diketahui peneliti. Wawancara mendalam ini dilakukan karena peneliti ingin mengetahui fokus makna dari ungkapan teks yang di sampaikan informan. Tahap kedua, peneliti mengumpulkan dokumen-dokumen terkait dengan penjabaran audit kesejahteraan rakyat. Selain makalah, peneliti juga mengumpulkan dokumen rencana strategi BPK hal ini dimaksudkan agar peneliti dapat melihat sejauh mana gambaran pemaknaan audit kesejahteraan dalam bentuk tindakan aksi BPK secara institusi. Tahap yang ketiga adalah peneliti mengumpulkan jurnal-jurnal yang berkaitan dengan pemaknaan kesejahteraan rakyat, dimaksudkan agar peneliti dapat melihat dari sudut pandang yang lebih komprehensif. 


\section{KERANGKA KONSEP}

UUD 1945 lebih banyak menggunakan terminologi kemakmuran rakyat dalam batang tubuhnya. Selain terdapat pada Pasal 23 ayat (1), kemakmuran rakyat juga digunakan dalam Pasal 33 UUD 1945 yang secara lengkap berbunyi "bumi dan air dan kekayaan alam yang terkandung di dalamnya dikuasai oleh negara dan dipergunakan sebesar-besarnya untuk kemakmuran rakyat". Namun dalam Pembukaan UUD 1945 tujuan ke-empat bernegara adalah memajukan kesejahteraan umum. Perbedaan kemakmuran dan kesejahteraan menurut Sumner (1996:7) terletak pada lingkupnya. Lingkup kesejahteraan hanya terletak pada kesejahteraan ekonomi seperti kemampuan manusia untuk memenuhi kebutuhan berupa sandang, pangan, perumahan, kesehatan dan pendidikan, dalam lingkup yang lebih luas kemakmuran terdiri dari kesejahteraan ekonomi dan non ekonomi (Akbar dan Djazuli, 2015:7).

Kemakmuran dalam sudut pandang ekonomi didefinisikan sebagai kondisi dalam siklus ekonomi tercapainya tingkat pengangguran yang relatif rendah, pendapatan tinggi yang merata, serta tingginya kemampuan daya beli (jika tingkat inflasi dijaga dalam kondisi yang rendah). Sedangkan kesejahteraan menurut ekonomi merupakan sebuah cabang dari ilmu ekonomi yang memfokuskan pada alokasi optimal dari sumber daya dan bagaimana hal ini berpengaruh terhadap kesejahteraan sosial. Ekonomi kesejahteraan juga menganalisis bagaimana barang-barang dapat didistribusikan sehingga tercapai kondisi saat ini. Hal ini berhubungan dengan studi distribusi pendapatan dan dampaknya terhadap barang-barang secara umum. Dari dua definisi tersebut dapat dilihat perbedaannya pada pendekatan yang digunakan. Kemakmuran secara umum menggunakan pendekatan ekonomi makro seperti tingkat pengangguran, pendapatan dan kemampuan daya beli. Sedangkan kesejahteraan pada dasarnya menggunakan pendekatan analisis ekonomi mikro berupa optimalisasi penggunaan sumber daya ekonomi atau efisiensi yang dianalisis secara agregat Indikator-indikator kesejahteraan ekonomi yang digunakan, diantaranya (Akbar dan Djazuli, 2015:7):

1. Tingkat pertumbuhan ekonomi

2. Produk Domestik Regional Bruto (PDRB) per kapita

3. Tingkatkemiskinan

4. Indeks Pembangunan Manusia (IPM)

5. Tingkat pengangguran

6. Rasio Gini

Senada dengan hal tersebut di atas, indikator tingkat kesejahteraan pada dasarnya merupakan output ataupun outcome yang dihasilkan dari sumber daya ekonomi, terutama sumber daya keuangan yang dibelanjakan untuk program-program atau aktivitas yang diharapkan dapat memberikan dampak bagi peningkatan kesejahteraan rakyat. indikator kesejahteraan rakyat bisa dilihat dari tingkat pengangguran, tingkat kemiskinan, IPM, dan gini ratio (Azis, 2017)

Dengan dilaksanakannya desentralisasi, daerah diharapkan dapat memberikan pelayanan yang lebih cepat dan bermuara pada peningkatan daya saing ekonomi dan kesejahteraan rakyat daerah otonom diikuti dengan pengelolaan keuangan yang transparan dan akuntabel (Akbar dan Djazuli, 2015:3). Keberhasilan pengelolaan keuangan daerah tetapi tanpa menyertakan peningkatan kesejahteraan masyarakat akan menampilkan gambaran kesenjangan dan ketimpangan dalam kehidupan masyarakat. Kesejahteraan masyarakat adalah suatu kondisi yang memperlihatkan tentang kehidupan masyarakat yang dapat dilihat dari standar kehidupan masyarakat (Badruddin, 2012). 
Reformasi organisasi sektor publik, khususnya pada pemerintahan di beberapa negara didasarkan pada asumsi bahwa dengan meningkatkan kualitas mekanisme tata kelola dan akuntabilitas akan meningkatkan kinerja organisasi sektor publik (Aucoin, 1990 dalam editorial, 2013). Khususnya di Indonesia, hubungan antara tata kelola dan akuntabilitas dengan kinerja Pemerintah telah menjadi perhatian banyak peneliti (diantaranya Mustikarini dan Fitriasari, 2012; Budianto, 2012; Pamungkas, 2012; Marfiana dan Kurniasih, 2013, Asmoko, 2015). Hasil penelitian mereka diantaranya menemukan bahwa terdapat pengaruh temuan audit dan karateristik pemerintah daerah terhadap kinerja pemerintah daerah, namun khususnya terkait dengan opini audit, pengaruhnya masih beragam terhadap kinerja Pemerintah.

Dalam konteks penelitian ini, opini audit atas Laporan Keuangan Pemerintah Daerah (LKPD) diasumsikan berfungsi sebagai dasar legitimasi yang diberikan oleh pihak-pihak yang berkepentingan terhadap Pemerintah Daerah, khususnya masyarakat daerah. Ketika opini audit sesuai dengan harapan masyarakat maka hal tersebut akan berdampak pada meningkatnya sumber daya masyarakat yang diberikan kepada Pemerintah Daerah, khususnya dalam bentuk pajak daerah dan retribusi daerah (Pendapatan Asli Daerah/PAD), sehingga dapat dikatakan bahwa opini audit berpengaruh positif terhadap pencapaian realisasi pendapatan Pemerintah Daerah, khususnya PAD yang seharusnya juga memberikan dampak bagi peningkatan kesejahteraan rakyat.

Undang-Undang Dasar 1945 Pasal 23 ayat ( 1 ) berbunyi : "anggaran pendapatan dan belanja negara sebagai wujud dari pengelolaan keuangan negara ditetapkan setiap tahun dengan undang-undang dan dilaksanakan secara terbuka dan bertanggungjawab untuk sebesar-besarnya kemakmuran rakyat". Pada Pasal ini secara tidak langsung disebutkan bahwa untuk mencapai suatu kemakmuran bagi rakyat ada dua faktor penentu dalam pelaksanaan pengelolaan keuangan yang baik, yaitu transparan atau keterbukaan serta akuntabel atau bertanggung jawab. Dalam rangka mencapai visinya, sebagai lembaga pemeriksa keuangan negara, BPK harus berperan aktif dalam mendorong pemerintah guna mencapai tata kelola keuangan negara yang transparan dan akuntabel. Salah satu bentuk pengembangan audit yang kini dicanangkan BPK adalah audit yang berbasis kesejahteraan rakyat, seperti yang diungkapkan oleh ketua BPK, Harry Azhar Azis. Dengan model audit ini, BPK diharapkan mampu mendorong para penyelenggara pemerintahan supaya anggaran dapat dimanfaatkan sebesar-besarnya guna tercipta kesejahteraan rakyat.

\section{HASIL DAN PEMBAHASAN}

Dengan mengacu pada kriteria kesejahteraan rakyat secara sederhana yang meliputi penurunan penduduk miskin, pengangguran yang semakin menurun, angka IPM yang semakin meningkat, serta gini ratio yang juga semakin menurun (Azis, 2017), maka seharusnya daerah-daerah yang memiliki opini kinerja keuangan WTP akan menunjukkan hasil yang selaras dengan kriteria kesejahteraan rakyat tersebut. Akan tetapi, berdasarkan data time series dua tahun terakhir dari BPS menunjukkan bahwa beberapa daerah justru memperlihatkan hasil yang sebaliknya. 
Tabel 1.

Perbandingan Provinsi Penerima WTP dengan Kriteria Persentase Penduduk Miskin, Tingkat Pengangguran Terbuka, dan Gini Ratio Tahun 2016-2017

\begin{tabular}{|c|c|c|c|c|c|c|c|c|c|c|c|}
\hline \multirow[b]{3}{*}{ No } & \multirow{3}{*}{$\begin{array}{c}\text { Provinsi } \\
\text { RATA-RATA } \\
\text { INDONESIA }\end{array}$} & \multicolumn{2}{|c|}{$\begin{array}{l}\text { \% Penduduk } \\
\text { Miskin }\end{array}$} & \multirow[b]{3}{*}{ No } & \multirow{3}{*}{$\begin{array}{l}\text { Provinsi } \\
\text { RATA-RATA } \\
\text { INDONESIA }\end{array}$} & \multicolumn{2}{|c|}{$\begin{array}{c}\text { Tingkat } \\
\text { Pengangguran } \\
\text { Terbuka (TPT) }\end{array}$} & \multirow{3}{*}{ No } & \multirow{2}{*}{ Provinsi } & \multicolumn{2}{|c|}{ Gini Ratio } \\
\hline & & 2016 & 2017 & & & 2016 & 2017 & & & 2016 & 2017 \\
\hline & & 10,70 & 10,12 & & & 5,61 & 5,50 & & $\begin{array}{l}\text { RATA-RATA } \\
\text { INDONESIA }\end{array}$ & 0,394 & 0,391 \\
\hline 1 & Kep. Riau & 5,84 & 6,13 & 1 & $\begin{array}{l}\text { Sumatera } \\
\text { Barat }\end{array}$ & 5,09 & 5,58 & 1 & $\begin{array}{l}\text { Sumatera } \\
\text { Utara }\end{array}$ & 0,312 & 0,335 \\
\hline 2 & Banten & 5,36 & 5,59 & 2 & $\begin{array}{l}\text { Sumatera } \\
\text { Selatan }\end{array}$ & 4,31 & 4,39 & 2 & $\begin{array}{l}\text { Sulawesi } \\
\text { Utara }\end{array}$ & 0,379 & 0,394 \\
\hline 3 & $\begin{array}{l}\text { Kalimantan } \\
\text { Selatan }\end{array}$ & 4,52 & 4,70 & 3 & $\begin{array}{l}\text { DI } \\
\text { Yogyakarta }\end{array}$ & 2,72 & 3,02 & 3 & NTB & 0,365 & 0,378 \\
\hline 4 & $\begin{array}{l}\text { Kalimantan } \\
\text { Timur }\end{array}$ & 6,00 & 6,08 & 4 & Banten & 8,92 & 9,28 & 4 & $\begin{array}{l}\text { Sulawesi } \\
\text { Tenggara }\end{array}$ & 0,388 & 0,404 \\
\hline 5 & $\begin{array}{l}\text { Sulawesi } \\
\text { Tengah }\end{array}$ & 14,09 & 14,22 & 5 & $\begin{array}{l}\text { Kalimantan } \\
\text { Barat }\end{array}$ & 4,23 & 4,36 & 5 & $\begin{array}{l}\text { Kalimantan } \\
\text { Timur }\end{array}$ & 0,328 & 0,333 \\
\hline 6 & $\begin{array}{l}\text { Sulawesi } \\
\text { Selatan }\end{array}$ & 9,24 & 9,48 & 6 & $\begin{array}{l}\text { Kalimantan } \\
\text { Utara }\end{array}$ & 5,23 & 5,54 & 6 & Jawa Timur & 0,402 & 0,415 \\
\hline 7 & $\begin{array}{l}\text { Maluku } \\
\text { Utara }\end{array}$ & 6,41 & 6,44 & 7 & $\begin{array}{l}\text { Sulawesi } \\
\text { Utara }\end{array}$ & 6,18 & 7,18 & 7 & $\begin{array}{l}\text { Sulawesi } \\
\text { Selatan }\end{array}$ & 0,400 & 0,429 \\
\hline & & & & 8 & $\begin{array}{l}\text { Sulawesi } \\
\text { Tengah }\end{array}$ & 3,29 & 3,81 & 8 & $\begin{array}{l}\text { DI } \\
\text { Yogyakarta }\end{array}$ & 0,425 & 0,440 \\
\hline & & & & 9 & $\begin{array}{l}\text { Sulawesi } \\
\text { Selatan }\end{array}$ & 4,80 & 5,61 & 9 & $\begin{array}{l}\text { Kalimantan } \\
\text { Utara }\end{array}$ & 0,308 & 0,313 \\
\hline & & & & 10 & $\begin{array}{l}\text { Sulawesi } \\
\text { Tenggara }\end{array}$ & 2,72 & 3,30 & 10 & $\begin{array}{l}\text { Maluku } \\
\text { Utara }\end{array}$ & 0,317 & 0,330 \\
\hline & & & & 11 & Gorontalo & 2,76 & 4,28 & & & & \\
\hline & & & & 12 & Maluku & 7,05 & 9,29 & & & & \\
\hline & & & & 13 & Maluku Utara & 4,01 & 5,33 & & & & \\
\hline & & & & 14 & Papua & 3,35 & 3,62 & & & & \\
\hline
\end{tabular}

Sumber : Badan Pusat Statistik, 2016-2017

Khusus untuk data Indeks Pembangunan Manusia (IPM) tidak disajikan, karena seluruh provinsi menunjukkan hasil peningkatan yang positif. Namun demikian, pada tabel 2 di atas terlihat bahwa beberapa provinsi penerima opini WTP masih belum dapat menunjukkan hasil yang positif pada beberapa kriteria kesejahteraan rakyat lainnya (persentase penduduk miskin, tingkat pengangguran terbuka, dan gini ratio). Data di atas memperlihatkan tujuh provinsi penerima WTP justru mengalami peningkatan persentase penduduk miskin, 14 provinsi penerima WTP mengalami peningkatan tingkat pengangguran terbuka, dan 10 provinsi penerima WTP mengalami peningkatan kesenjangan kesejahteraan (gini ratio).

Bahkan, hasil mengejutkan ditunjukkan oleh Provinsi Sulawesi Selatan yang dalam dua tahun terakhir memiliki nilai negatif pada ketiga kriteria tersebut. Meskipun menerima opini WTP dalam hal pengelolaan keuangan daerah, namun dampak perolehan WTP tersebut justru belum mampu menurunkan persentasi penduduk miskin, mengurangi tingkat pengangguran terbuka, serta memperkecil gap gini ratio. Hal ini menunjukkan bahwa di satu sisi opini WTP belum mampu secara selaras mempertimbangkan kriteria kesejahteraan masyarakat dalam proses auditnya, serta di sisi lainnya adalah program dan kegiatan yang dijalankan oleh pemerintah provinsi tersebut belum 
mampu secara tepat mengarah pada peningkatan kesejahteraan masyarakatnya. Oleh karenanya, diperlukan audityang lebih lengkap dengan memperhitungkan pula aspek atau indikator kesejahteraan masyarakat.

Gagasan perlunya audit kesejahteraan dilakukan oleh BPK pertama kali diungkap oleh Ketua BPK Harry Azhar Azis dalam menyikapi realita bahwa opini WTP atas pengelolaan keuangan pemerintah yang relatif belum mampu secara selaras menunjukkan peningkatan kesejahteraan masyarakat. Kondisi ini juga merupakan wujud perhatian informan dalam memaknai kewajiban moral BPK sebagaimana tercantum dalam UUD Tahun 1945 Pasal 23 ayat 1.

“...Anggaran Pendapatan dan Belanja Negara sebagai wujud dari pengelolaan keuangan negara ditetapkan setiap tahun dengan undang-undang dan dilaksanakan secara terbuka dan bertanggung jawab untuk sebesar-besarnya kemakmuran rakyat. Jadi ada 3 unsur, yaitu terbuka, bertanggungjawab, dan digunakan sebesarbesarnya untuk kemakmuran rakyat.unsur ketiga yang disebutkan dalam UU adalah "digunakan sebesar-besarnya untuk kemakmuran rakyat", unsur ini yang tidak pernah disentuh....

...Kita mengaudit sisi undang-undang atau peraturan yang menyangkut pengelolaan keuangan negara yaitu UU APBN dan Perda APBD. Kita mulai masuk juga ke perencanaan, kita masuk ke Perpres RPJMN, RKP, dan sebagian dana pusatyg ditransfer ke daerah, connectingnya dalam konteks kesejahteraan rakyat...

....Ini ujungnya semua di perencanaan... Hal yang penting dalam melakukan perencanaan adalah adanya data, karena itulah yang menjadi sumber kita mengambil keputusan dalam perencanaan, mau dialokasikan ke mana, laporan yang saya terima tidak ada sinkronisasi data, masing-masing bergerak di sektornya. Saya sering mengambil contoh, mesti ada anggaran di bidang kesejahteraan rakyat, jadi bagaimana cara untuk mengurangi kemiskinan, mesti ada anggaran untuk mengatasi kemiskinan...

...Bagaimana cara pemeriksaannya? yaitu melalui audit kinerja., ada 3 prinsip dalam UU yaitu : ekonomis, efisien dan efektif.. metodenya sedang dirumuskan dan merupakan kombinasi audit... atas indikator kemiskinan, pengangguran, gini ratio, dan IPM..."

(Hasil wawancara dengan informan, 2017)

Dari hasil wawancara di atas dapat diinterpretasikan beberapa hal terkait dengan kesejahteraan rakyat dan kaitannya dengan opini WTP. Pertama, kebutuhan akan audit kesejahteraan rakyat; Kedua, perlunya BPK melakukan audit sejak tahapan perencanaan; dan Ketiga, kombinasi audit pemeriksaan dengan memperhitungkan indikator kesejahteraan rakyat. Pemaknaan kesejahteraan dalam audit kesejahteraan diartikan sebagai keselarasan pencapaian kesejahteraan rakyat menurut indikator ekonomi yaitu, penurunan angka kemiskinan, penurunan angka pengangguran, tingkat kesenjangan (gini ratio) yang makin berkurang, serta peningkatan nilai indeks pembangunan manusia dengan tingkatan opini yang diberikan BPK (WTP/ WDP/ TMP/ TW) kepada pemerintah daerah.

Pemaknaan digunakan "sebesar-besarnya untuk kesejahteraan atau kemakmuran rakyat" menjadi ukuran dan unsur penting pengelolaan keuangan pemerintah, disamping menjadi tuntutan untuk menyempurnakan prinsip filosofis tata kelola keuangan negara yang baik. "sebesar-besarnya" 
menunjukkan makna bahwa penganggaran program dan kegiatan pemerintah secara dominan haruslah berorientasi pada peningkatan kesejahteraan masyarakat dan atau memberikan manfaat bagi peningkatan kualitas kehidupan masyarakat. Dengan demikian, hadirnya wacana audit yang memperhitungkan kesejahteraan rakyat menjadi jawaban untuk melengkapi prinsip tersebut.

BPK diberi amanah oleh negara untuk memeriksa pengelolaan dan tanggung jawab keuangan negara. Sehingga memiliki peran yang cukup signifikan pula dalam rangka mewujudkan kesejahteraan rakyat, agar setiap anggaran negara dan daerah dapat dirasakan manfaatnya oleh seluruh lapisan masyarat, dan disinilah peran BPK untuk memeriksa kemanfaatan tersebut. Pemeriksaan terhadap kesejahteraan masyarakat tersebut masih belum tersentuh dengan model audit yang ada saat ini, sehingga beberapa bukti kuantitatif memperlihatkan bahwa opini WTP belum dapat menggambarkan kemakmuran dan kesejahteraan masyarakat suatu daerah. Secara umum, tidak ada perbedaan mendasar antara kemakmuran dan kesejahteraan. Namun jika dilihat dari sudut pandang ekonomi, kemakmuran mempunyai lingkup yang lebih luas dibandingkan dengan kesejahteraan, karena kemakmuran terdiri dari kesejahteraan ekonomi dan non ekonomi. Sedangkan kesejahteraan dalam beberapa literatur hanya menyangkut kesejahteraan ekonomi (Akbar dan Djazuli, 2015:2)

Adanya istilah audit kesejahteraan juga menandakan peningkatan dari paradigma lama di mana BPK melakukan audit kinerja terhadap pemerintah secara tersebar dan tidak fokus pada sejumlah program pembangunan. Dengan ini, BPK diyakini dapat memberikan penilaian yang lebih holistik dan komprehensifatas program pembangunan. Dimasukkannya audit kesejahteraan sebagai indikator dalam pemberian opini pengelolaan keuangan pemerintah daerah diharapkan memberikan dampak yang luas lagi yakni mendorong pemerintah dalam memperbaiki kebijakan publik dan kualitas belanja pemerintah guna mencapai tujuan bernegara.

Bukan tanpa alasan mengapa metode pemeriksaan perlu dilakukan perubahan. Belakangan ini, pemberian opini WTP atas pengelolaan keuangan kepada entitas yang diperiksa dirasa tidak cukup menjawab tuntutan masyarakat terhadap akuntabilitas, Karena penilaian yang diberikan hanya berdasarkan kesesuaian dengan Standar Akuntansi Pemerintah (SAP). Namun, secara empiris bisa kita temukan, beberapa pemerintah daerah yang sudah beberapa kali memperoleh opini WTP, tetapi tidak selalu berhasil dalam meningkatkan kesejahteraan rakyat. Bahkan, ada pemerintah daerah yang mengalami penurunan opini, tetapi justru indikator kemakmurannya relatif baik. Dengan demikian, belum ada korelasi yang jelas antara perolehan opini dan peningkatan kesejahteraan rakyat.

Pemeriksaan saat ini lebih kepada sisi implementasi anggaran, dan bagaimana pelaporannya. Ini yang disebut dengan audit keuangan. Sementara, apakah anggaran yang digunakan tersebut memberikan manfaat yang maksimal untuk kesejahteraan rakyat, belum banyak dilakukan auditnya oleh BPK. Di sinilah audit kesejahteraan sangat penting dilaksanakan. Dengan demikian, ada dua sisi yang dinilai oleh BPK, yaitu sisi pertanggungjawaban keuangan dan pertanggungjawaban kinerja atau pemanfaatannya. Oleh karenanya, BPK perlu mendorong pencapaian opini laporan keuangan dengan kemampuan instansi dalam melaksanakan program-program peningkatan kesejahteraan rakyat. BPK perlu memprioritaskan pemeriksaan kinerja atas program-program yang mampu menekan tingkat kemiskinan, menekan angka pengangguran, dan mengurangi angka kesenjangan pendapatan. Selain itu, program yang bisa meningkatkan indeks pembangunan manusia meliputi kesehatan, pendidikan, dan peningkatan daya beli masyarakat. Jika hal ini bisa dilaksanakan, BPK dapat mempertegas manfaat hasil pemeriksaannya dengan upaya peningkatan kesejahteraan rakyat.

BPK tentu tidak mungkin secara langsung bersentuhan dengan kesejahteraan rakyat itu sendiri. Namun, melalui saran perbaikan audit agar pemerintah membangun sistem belanja yang lebih ekonomis, efektif dan efisien. BPK mengaudit melalui sisi UUAPBN dan Perda APBD. Selain itu, disisi perencanaan BPK melihat Peraturan Presiden tentang RPJMN, RKP, dan sebagian dana 
pusat yg ditransfer ke daerah, yang memiliki connecting dalam konteks kesejahteraan rakyat, baik berkaitan dengan program yang langsung dan program lain misalnya infrastruktur yang meningkatkan kesejahteraan secara tidak langsung, sehingga dapat selaras dalam mewujudkan Indonesia menjadi negara yang sejahtera.

Adapun metode audit kesejahteraan sendiri menurut informan masih sedang dirumuskan. Metode yang diusulkan merupakan kombinasi audit. Intinya untuk mengukur kemakmuran atau kesejahteraan masyarakat setidaknya mencakup empat indikator utama yaitu, kemiskinan yang menurun, pengangguran yang terus menurun, kesenjangan pendapatan atau gini rasio yang turut menurun, dan indikator indeks pembangunan manusia (IPM) yang meningkat. Khusus untuk IPM, unsur penyusunnya terdiri atas tiga indikator yaitu kesehatan, pendidikan, ditambah dengan daya beli masyarakat yang juga harus menunjukkan kecenderungan peningkatan.

Strategi audit kesejahteraan rakyat secara garis besar akan melebur dalam audit kinerja. Audit dilakukan pada program/bidang yang langsung berkaitan dan bisa dirasakan oleh masyarakat, dengan berpedoman pada prinsip ekonomis, efisien dan efektif. Audit kinerja dilakukan karena audit keuangan saja dianggap tidak cukup untuk memstikan anggaran negara digunakan untuk kemakmuran rakyat. Audit keuangan hanya memastikan penggunaan anggaran wajar mengikuti peraturan yang berlaku, namun tidak menjamin bahwa setiap rupiah membuat masyarakat sejahtera. Oleh karenanya, audit kinerja memastikan pengguna anggaran akan lebih proporsional dalam mengalokasikan dana untuk kepentingan masyarakat.

Jika digambarkan atau berkaca dengan misalnya, peningkatan APBN pada Tahun 2004 sebesar 450 Triliun dan APBN Tahun 2014 sebesar 2000 Triliun, maka seharusnya dapat diperhitungkan berapa penurunan kemiskinan yang seharusnya dicapai. Dengan menggunakan cost benefit ratio secara gampang dapat disimpulkan bahwa pertumbuhan APBN yang hampir 500\%, belum memberikan benefit berupa penurunan kemiskinan (belum mencapai $>1$ ). Analogi inilah yang menjadi alasan urgensi perlunya memperhitungkan setiap rupiah yang dikeluarkan dengan pengaruhnya terhadap peningkatan kesejahteraan publik. Dengan kata lain, jika dikaitkan dengan tata kelola keuangan pemerintah, maka agar dapat mengurangi terjadinya paradoks antara Opini BPK yang mencerminkan akuntabilitas dengan tingkat kesejahteraan rakyat diperlukan audit kinerja yang berfokus pada kesejahteraan rakyat.

Selain pada proses pelaksanaan yang dilakukan secara bertahap dengan menilai ekonomis, efisiensi, dan efektivitas kegiatan instansi pemerintah, audit kinerja juga perlu fokus pada tahap perencanaan. Dimana pada tahapan perencanaan ini merupakan tahapan dimana para pengguna anggaran menentukan keputusan dalam mengarahkan anggaran yang dimilikinya ke program tertentu, hal ini menjadi salah satu titik krusial yang perlu dicermati oleh auditor. Audit kinerja akan menyasar pada program-program tertentu pada lembaga pemerintah tertentu, dengan mengacu pada indikator target pembangunan yang telah ditentukan. Oleh karena itu, BPK juga harus mulai meningkatkan kemampuannya dalam melakukan pemeriksaan kinerja. Hal ini penting karena jika satu saat Laporan Keuangan Kementerian Negara/ Lembaga (LKKL) dan Laporan Keuangan Pemerintah Daerah (LKPD) mayoritas sudah WTP, maka BPK harus sudah siap dan mampu melakukan pemeriksaan kinerja dengan kualitas yang semakin baik.

BPK diharapkan dapat memberikan rekomendasi kepada pemerintah atau entitas pada desain kebijakan, strategi, dan program dalam kaitannya dengan penganggaran yang dilakukan dalam tahap perencanaan, sehingga tujuan pembangunan dapat diwujudkan dan pemborosan sumber daya dihindari. Dengan melakukan strategi diferensiasi, yaitu menggunakan strategi audit dengan tema meningkatkan kesejahteraan rakyat serta dapat pula dengan menggabungkan tiga jenis audit yang ada yaitu, audit keuangan, audit kinerja, dan audit dengan tujuan tertentu untuk mengaudit program- 
program pembangunan pemerintah terkait dengan tema kesejahteraan rakyat serta pelaksanaan audit kesejahteraan tersebut dilakukan dari tahap perencanaan, pelaksanaan, dan pelaporan maka, diharapkan opini atas pengelolaan keuangan pemerintah yang dikeluarkan oleh BPK benar-benar akan mencerminkan pencapaian kinerja pemerintah daerah dalam meningkatkan kesejahteraan masyarakatnya.

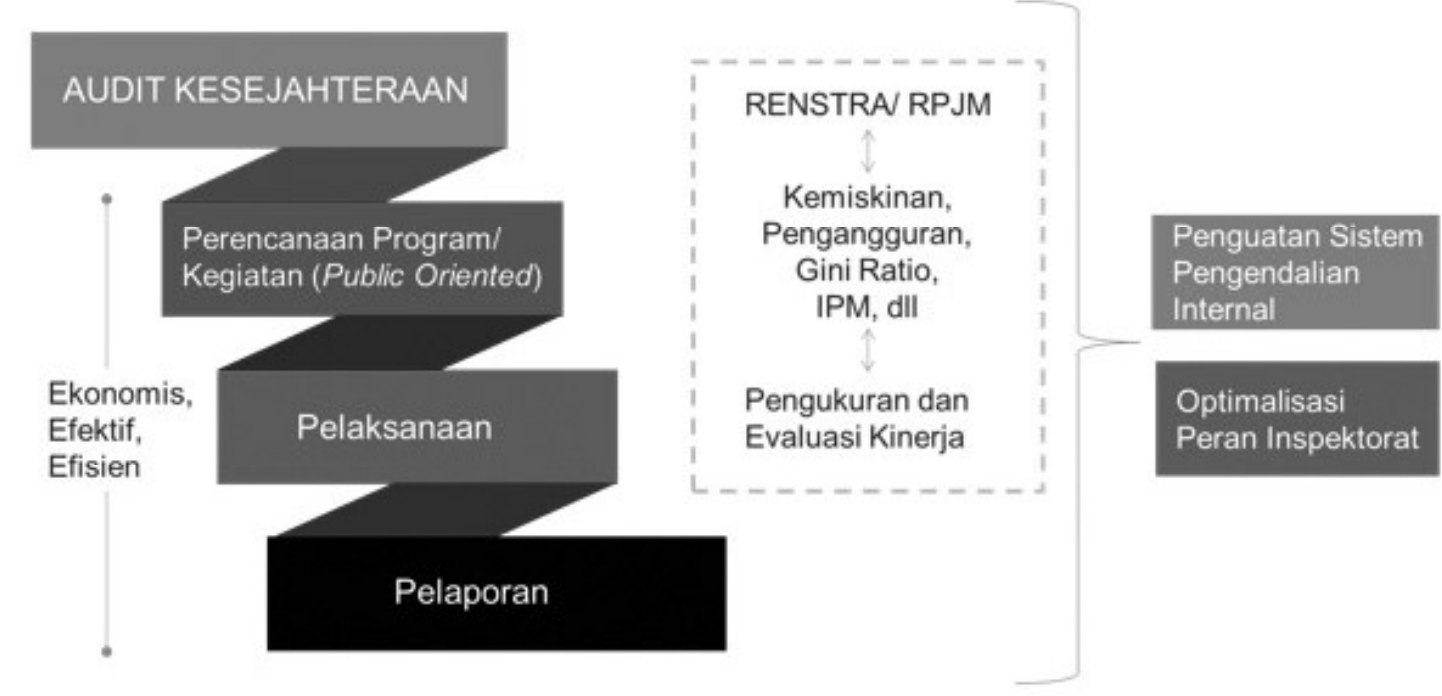

Sumber : Analisa Penulis, 2018

\section{Gambar 1.}

Optimalisasi Pengawasan, Pengendalian, dan Pemeriksaan Dalam Menunjang Pelaksanaan Audit Kesejahteraan Publik Pada Tata Kelola Keuangan Pemerintah Daerah

Pada dimensi yang lain, upaya mewujudkan audit kesejahteraan yang utuh sebagai sebuah sistem holistik tidak serta merta dibebankan kepada BPK semata. Perlu dukungan dari internal pemerintah daerah sendiri untuk mewujudkannya, mulai dari penyusunan rencana kerja dan kegiatan yang berorientasi pada kepentingan publik, pelaksanaan yang sesuai koridor yang ditetapkan, perlunya terus dilakukan pengukuran dan evaluasi atas capaian kinerja program/kegiatan, hingga pada pelaporan yang sesuai ketentuan. Untuk mewujudkan hal tersebut, diperlukan penguatan atas sistem pengendalian internal pemerintah daerah yang terbangun dengan baik.

Selanjutnya adalah peran pengawasan oleh inspektorat agar seluruh kegiatan pemerintah dapat berjalan dengan baik serta beorientasi pada pencapaian kesejahteraan masyarakat. Inspektorat berperan dalam melakukan pendampingan akuntabilitas mulai dari tahapan perencanaan, pelaksanaan, hingga pelaporan serta melakukan koreksi atas kemungkinan penyimpangan yang terjadi.

Jika komponen sistem pengendalian internal serta inspektorat ini dapat berperan dengan baik, tentu akan memudahkan BPK dalam melakukan pemeriksaan atau audit kesejahteraan. Audit kesejahteraan akan memeriksa dengan prinsip ekonomis, efektif, dan efisien atas tata kelola keuangan pemerintah daerah serta dengan membandingkannya dengan capaian indikator-indikator kesejahteraan rakyat. Dengan demikian, diharapkan tidak hanya laporan keuangan pemerintah daerah saja yang tertata dengan baik dan rapi, tetapi juga pertanggung jawaban dan kemanfaatan atas setiap anggaran yang dikeluarkan bagi kepentingan kesejahteraan masyarakat dapat diwujudkan dengan baik. Sehingga dapat diwujudkan capain hasil opini BPK atas laporan keuangan pemerintah daerah yang dapat mencerminkan kondisi kesejahteraan masyarakat suatu daerah secara selaras dan relevan. 


\section{E. PENUTUP}

Secara faktual terdapat beberapa pemerintah daerah yang sudah mendapatkan opini WTP tetapi justru menunjukkan permasalahan kemiskinan, pengangguran, serta gini ratio yang timpang, dan terdapat daerah-daerah lainnya yang belum mendapatkan opini WTP tetapi memperlihatkan indikator kesejahterana rakyat yang positif. Kondisi ini tentu merupakan sebuah fenomena. Pemeriksaan BPK selama ini lebih cenderung masih melihat ke kelengkapan administrasi akuntabilitas, belum masuk pada upaya mengevaluasi keberhasilan perencanaan dan anggaran yang digunakan untuk kesejahteraan masyarakat. Oleh karenanya, untuk mengoptimalkan pengelolaan keuangan pemerintah daerah bagi kesejahteraan masyarakat, maka penelitian ini mendorong kepada BPK untuk memasukkan audit kesejahteraan dalam proses pemeriksaan keuangan pemerintah daerah mulai dari kegiatan perencanaan, pelaksanaan, hingga pada pelaporan yang secara konkrit mendukung pencapaian kesejahteraan masyarakat.

Audit kesejahteraan ini merupakan wacana atau pemikiran Ketua BPK dalam melihat fenomena paradoks yang terjadi yaitu tidak adanya keterkaitan akuntabilitas kinerja pemerintahan yang perwujudannya dibuktikan dengan perolehan opini WTP dengan tingkat kesejahteraan rakyatnya. Padahal secara filosofis, pengelolaan keuangan negara/ daerah dipergunakan secara terbuka, bertanggung jawab, dan sebesar-besarnya untuk kemakmuran rakyat.

Penelitian ini memiliki implikasi teoritis, yaitu memberikan bukti empiris untuk mendukung konsep Paton (1992) dan Sinclair (1995), bahwa akuntabilitas dimaknai secara beragam. Pada awalnya, pemerintah daerah dengan opini WTP memiliki makna Pemerintah Daerah tersebut memiliki akuntabilitas yang baik. Namun, setelah pandangan Ketua BPK ini hadir dengan wacana perlunya audit kesejahteraan rakyat, memberikan pemaknaan baru bahwa meski mendapatkan opini WTP, namun jika kondisi kesejahteraan rakyatnya menunjukkan kecenderungan penurunan, maka dapat dikatakan pemerintah daerah tersebut belum akuntabel.

Pemerintah daerah juga perlu lebih didorong agar menyusun perencanaan program dan kegiatan yang lebih berorientasi pada peningkatan kesejahteraan masyarakat. Upaya penyelarasan perencanaan strategis serta rencana dan target pembangunan nasional perlu dilaksanakan. Selanjutnya adalah pelaksanaan, evaluasi atas capaian kinerja, serta pelaporan yang berjalan tanpa penyimpangan. Untuk mengawal hal ini, diperlukan penguatan atas sistem pengendalian internal, serta pengawasan yang ketat dari inspektorat agar setiap pembelanjaan keuangan daerah sesuai dengan kebutuhan masyarakat.

\section{DAFTAR PUSTAKA}

Aditantra, Ikhwan Aryan. (2011). Analisis Pemahaman Laba dalam Penentuan Laba Optimal: Studi Kasus Pada pedagang Keliling. Skripsi. Fakultas Ekonomi, Universitas Diponegoro (18-22)

Akbar, Bahrullah dan Djazuli, Achmad. (2015). Audit Keuangan dan Kesejahteraan Rakyat (Studi pada Kabupaten Badung, Tabanan, dan Kota Denpasar) Tahun 2013. Jurnal Tata Kelola dan Akuntabilitas Keuangan Negara, Vol. 1(1), 1-19

Asmoko, Hindri. (2015). Korelasi Opini Audit BPK Atas LKKL Dengan Hasil Evaluasi LAKIP $K / L$. Retrieved 16 November 2015 from http://www.bppk.kemenkeu.go.id/publikasi/artikel/ 147- artikel-anggaran-dan-perbendaharaan/20424-korelasi-opini-audit-bpk-ataslkkldengan-hasil-evaluasi-lakip-k-l. 
Aucoin, P. (1990). Administrative Reform In Public Management: Paradigms, Principles, Paradoxes and Pendulums. Governance, 3(2), 115-137

Azis, Harry Azhar. (2017). BPK: WTP Tidak Berkolerasi dengan Kesejahteraan Rakyat. Retrieved 15 Mei 2017 from https://www.wartaekonomi.co.id/read141183/bpk-wtp-tidakberkolerasi-dengan-kesejahteraan-rakyat.html.

Azis, Harry Azhar. (2017). Perolehan WTP Belum Disertai Peningkatan Kesejahteraan Rakyat. Retrieved 29 Februari 2016 fromhttps://feb.ugm.ac.id/id/berita/738-perolehan-wtp-belumdisertai-peningkatan-kesejahteraan-rakyat

Badrudin, Rudy. (2012). Ekonomika Otonomi Daerah. Yogyakarta: UPP STIM YKPN

Badan Pemeriksa Keuangan-RI. (2018). Ikhtisar Hasil Pemeriksaan Semester II Tahun 2017. Jakarta-Maret 2018

Budianto, Wendy. (2012). Pengaruh Opini, Temuan Audit, dan Gender Terhadap Kinerja Penyelenggaraan Pemerintah Daerah Kabupaten/Kota di Indonesia 2008-2010. Skripsi. Depok: FE-UI

Editorial (2013), Public Sector Governance and Accountability. Critical Perspectives on Accounting, (24), 479-487

Faiz, Fakhruddin. (2002). Hermeneutika al-Qur'an. Yogyakarta: Qolam, Cet.III

Ferraz, C., \& Finan, F. (2007). Exposing Corrupt Politicians: The Effects of Brazil's Publicly Released Audits On Electoral Outcomes

Gabrini, C. J. (2013). The Effect Of Internal Audit On Governance: Maintaining Legitimacy of Local Government.Dissertations, The Florida State University

Marfiana, N., \& Kurniasih, L. (2013). Pengaruh Karakteristik Pemerintah Daerah dan Hasil Pemeriksaan Audit BPK Terhadap Kinerja Keuangan Pemerintah Daerah Kabupaten/Kota. Sustainable Competitive Advantage (SCA), 3(1)

Mustikarini, W.A., \& Fitriasari, D. (2012). Pengaruh Karakteristik Pemerintah Daerah dan Temuan Audit BPK Terhadap Kinerja Pemerintah Daerah Kabupaten/Kota di Indonesia Tahun Anggaran 2007. Proceedings of Simposium Nasional Akuntansi, 15.

Nyoman, S., Ni Made SU, dan I.N. Mahaendra Yasa. (2015). Dampak Kinerja Keuangan Daerah Terhadap Kesejahteraan Masyarakat Kabupaten/ Kota di Provinsi Bali. Jurnal Ekonomi dan Bisnis, 6 (3), 167-181

Palmer, Richard E. 2003. Hermeneutika, Teori Baru Mengenai Interpretasi, (Terjemahan Musnur Hery). Yogyakarta: Pustaka Pelajar

Pamungkas, B. (2012). Pengaruh Penerapan Akuntansi Sektor Publik dan Pengawasan Terhadap Kualitas Laporan Keuangan dan Implikasinya Terhadap Akuntabilitas Kinerja Instansi Pemerintah. Jurnal Ilmiah Ranggagading (JIR), 12(2), 82-93

Patton, J.M. (1992). Accountability and Governmental Financial Reporting. Financial Accountability and Management, 8 (3), 165-180

Power, M. K. (2003). Auditing and The Production of Legitimacy. Accounting, Organizations and Society, 28(4), 379-394 
Putry, NurAnita Chandra dan Badrudin, Rudy. (2017). Pengaruh Kinerja Keuangan Daerah Terhadap Opini Audit dan Kesejahteraan Masyarakat di Daerah Istimewa Yogyakarta. Jurnal Riset Manajemen dan Bisnis, 12 (1), 25-34

Sinclair, A. 1995. The Chameleon of Accountability : Forms and Discourses. Accounting, Organization, and Society, 20 (2/3), 219-237

Suartama, I. K., Nurdin, S., \& Susilo, F. S. (2015). Enhancing BPK RI'sAudit Design for People's Welfare: A Practical Approach. Jurnal Tata Kelola dan Akuntabilitas Keuangan Negara, 1(2), 173-190

Suchman, M. C. (1995). Managing Legitimacy: Strategic and Institutional Approaches. Academy of Management Review, 20(3), 571-610

Thiel, S. V., \& Leeuw, F. L. (2002). The Performance Paradox in The Public Sector. Public Performance and Management Review, 25, (March 2003)

Wahyuni, S. (2015). Qualitative Research Method Theory and Practice. 2nd ed. Salemba Empat. Jakarta 